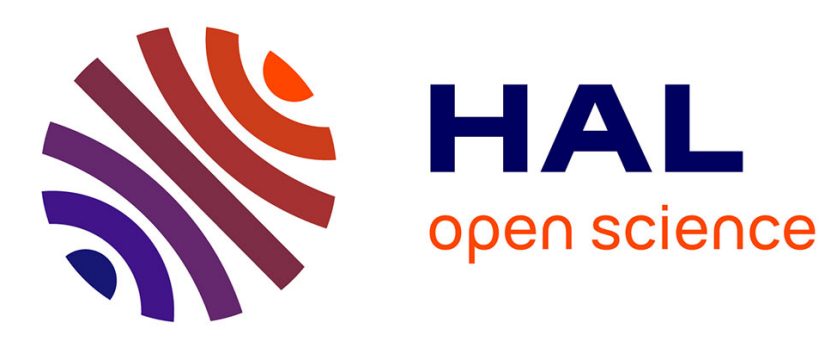

\title{
Magnetic Properties of Sr-M Ferrite Fine Particles
}

\author{
H. Yamamoto, H. Kumehara, R. Takeuchi, H. Nishio
}

\section{To cite this version:}

H. Yamamoto, H. Kumehara, R. Takeuchi, H. Nishio. Magnetic Properties of Sr-M Ferrite Fine Particles. Journal de Physique IV Proceedings, 1997, 07 (C1), pp.C1-535-C1-536. 10.1051/jp4:19971219 . jpa-00254891

\section{HAL Id: jpa-00254891 https://hal.science/jpa-00254891}

Submitted on 1 Jan 1997

HAL is a multi-disciplinary open access archive for the deposit and dissemination of scientific research documents, whether they are published or not. The documents may come from teaching and research institutions in France or abroad, or from public or private research centers.
L'archive ouverte pluridisciplinaire HAL, est destinée au dépôt et à la diffusion de documents scientifiques de niveau recherche, publiés ou non, émanant des établissements d'enseignement et de recherche français ou étrangers, des laboratoires publics ou privés. 


\title{
Magnetic Properties of Sr-M Ferrite Fine Particles
}

\author{
H. Yamamoto, H. Kumehara, R. Takeuchi and H. Nishio*
}

School of Science and Technology, Meiji University, 1-1-1 Higashimita, Tma-ku, Kawasaki 214, Japan

* Materials Research Center, TDK Corp., 570-2 Aza-Matsugashita, Minami-hatori, Narita 286, Japan

\begin{abstract}
Single phase Sr-M ferite fine particles were prepared by the chemical coprecipitation and subsequent heattreatment methods. The cliemical reagents used for an experiment are $\mathrm{FeCl}_{3} \cdot 6 \mathrm{H}_{2} \mathrm{O}$ and $\mathrm{Sr}\left(\mathrm{NO}_{3}\right)_{2}$. A solution containing $\mathrm{Fe}^{3+}$ and $\mathrm{Sr}^{2+}$ in the molar ratio $\left(\mathrm{Fe}^{3+} / \mathrm{Sr}^{2+}=11\right) 7.0 \sim 11.0$ was poured into a solution of $\mathrm{NaOH}(\mathrm{pH}=10 \sim 13)$. Aqueous suspensions containing the precipitated products were boiled for $2 \mathrm{~h} s$, and they were carefully washed, filtrated and dried at $80^{\circ} \mathrm{C}$ for $8 \mathrm{hs}$. The abtained fine particles were heated 800 to $1100^{\circ} \mathrm{C}$ lor $2 \mathrm{hs}$ in air to get single phase Sr-M ferrite fine particles. The optimum preparing condition of single phase Sr-M lerrite fine particles are as follows : reagents : $\mathrm{FeCl}_{3}$. $6 \mathrm{H}_{2} \mathrm{O}$ and $\mathrm{Sr}\left(\mathrm{NO}_{3}\right)_{2}$; the molar ratio: $\mathrm{Fe}^{3+} / \mathrm{Sr}^{2+}=8 ; \mathrm{pH}=13 ;$ the heat-treatment condition $: 900^{\circ} \mathrm{C} \times 2 \mathrm{hs}$ in air. The magnetic and physical properties are $\sigma_{s}=87.0 \times 10^{-6} \mathrm{~Wb} \cdot \mathrm{m} / \mathrm{kg}(69.2 \mathrm{emu} / \mathrm{g}), H_{\mathrm{s}}=501.3 \mathrm{kA} / \mathrm{m}(6.3 \mathrm{kOe}), \mathrm{H}_{\mathrm{save}}=945.4 \mathrm{kA} / \mathrm{m}(11.9$ $\mathrm{kOe}), \mathrm{Tc}=462^{\circ} \mathrm{C}$. the latice constants $\mathrm{a}=5.882 \times 10^{-10} \mathrm{~m}, \mathrm{c}=23.05 \times 10^{-16} \mathrm{~m}$. c/a $=3.919$, the activation energy $=182.0$ $\mathrm{k} J / \mathrm{mol}(43.5 \mathrm{kcal} / \mathrm{mol})$ and the average particle size $=0.2 \mu \mathrm{m}$.
\end{abstract}

\section{INTRODUCTION}

Many reports on various preparation methods of $\mathrm{BaO} \cdot 6 \mathrm{Fe}_{2} \mathrm{O}_{3}$ and $\mathrm{SrO} \cdot 6 \mathrm{Fe}_{2} \mathrm{O}_{3}$ lerrite fine particles have been presented[1] [7]. In these methods, $\mathrm{BaO} \cdot 6 \mathrm{Fe}_{2} \mathrm{O}_{3}$ ferrite fine particles prepared by the chemical coprecipitation and subsequent heat-treatment methods are gained the single phase and the high coercivity and magnetization. However $\mathrm{SrO} \cdot 6 \mathrm{Fe}_{2} \mathrm{O}_{3}$ ferrite fine particles prepared by this method are not gained the single phase (finally, to remove the other phase need to acid-treatment[6]), and their magnetization is low.

This experiment carried out to investigate the single phase Sr-M ferrile fine particles prepared by the chemical coprecipitation and subsequent heat-treatment methods.

\section{EXPERIMENTAL PROCEDURE}

The chemical reagents used for an experinent are $\mathrm{SrCl}_{2} \cdot 6 \mathrm{H}_{2} \mathrm{O}, \mathrm{Sr}\left(\mathrm{NO}_{3}\right)_{2}, \mathrm{FeCl}_{3} \cdot 6 \mathrm{H}_{2} \mathrm{O}$ and $\mathrm{Fe}\left(\mathrm{NO}_{3}\right) \cdot 9 \mathrm{H}_{2} \mathrm{O}$. A solution containing $\mathrm{Fe}^{3+}$ and $\mathrm{Sr}^{2+}$ in the molar ratio $\left(\mathrm{Fe}^{3+} / \mathrm{Sr}^{2+}=11\right) 7.0 \sim 12.0$ was poured into a solution of $\mathrm{NaOH}$ ( $\mathrm{pH}=10 \sim 13$ ). Aqueous suspensions containing the precipitaled products were boiled for $2 \mathrm{hs}$, and they were carefully washed, filtrated and dried at $80^{\circ} \mathrm{C}$ for 8 hs. And in the molar ratio $n=10 \sim 12$, treatment aftercoprecipitation was tried three process (1 boiling only, 2.boiling and washing, and 3 . without boiling and washing). The obtained fine particles were healed 800 to $1100^{\circ} \mathrm{C}$ for $2 \mathrm{hs}$ in air to get single phase Sr-M ferrite fine particles. The magnetic properties, the distribution of anisotropy ficld and Curie temperature of these isotropic particles were measured by a vibrating sample magnetometer. The saturation magnetization $\left(\sigma_{s}\right)$ was measured by applying a magnetic field of $1600 \mathrm{kA} / \mathrm{m}$ using by a VSM, and was calculated by $1 / \mathrm{H}^{2}$. The crystal structural analysis was carried out by X-ray diffraction patterns recorded using FeK $\alpha$ radiation, while the particle size was examined by SEM and TEM. The formation of Sr-M ferrite and the activation energy wore examined by DTA and TG scans for the coprecipitated particles with various heating rates between 2 ${ }^{\circ} \mathrm{C} / \mathrm{min}$ and $20^{\circ} \mathrm{C} / \mathrm{min}$. For comparison $\mathrm{BaM}$ and SrM ferrite fine particles, BaM ferrite fine particles were prepared by the chemical coprecipitation and subsequent heat-treatment methods using reagent of $\mathrm{Ba}\left(\mathrm{NO}_{3}\right)_{2}$ and $\mathrm{FeCl}_{3} \cdot 6 \mathrm{H}_{2} \mathrm{O}$ in molar ratio $n=10.5$.

\section{RESULTS AND DISCUSSION}

The preparation of Sr-M ferrite fine paritcies using with various combinations of regents was attempted. As a result, good magnetic properties of $\mathrm{Sr}-\mathrm{M}$ lerrite line particles was obtained using with the combination of $\mathrm{FeCl}_{3} \cdot 6 \mathrm{H}_{2} \mathrm{O}$ and $\mathrm{Sr}\left(\mathrm{NO}_{3}\right)_{2}$ regents. 
Until now; Sr-M ferrite tine particles prepared by chemical coprecipitation and subsequent heat treatment is not oblained $M$-type single phase in molar ratio $n=10.5$. So, the experiment carricd out to change the molar ratio $\mathrm{ll}=7 \sim 12.0$.

Fig. 1 shows the elfed of $n=\mathrm{Fe}^{3+} / \mathrm{Sr}^{2}$ ratio on magnelic properties of $\mathrm{Sr}-\mathrm{M}$ lerrite line particles. As scen from the ligure, good magnetic properties ol these particles was gained when was $\|=\$ .0 \sim 9.0$. The XRD patterns of these specimens indicated that these particles of $n=7.0 \sim 9.5$ show the $\mathrm{Sr}-\mathrm{M}$ single phase, and sample of $n>9.5$ was complex phases(Fig.2). Therclore, the experiment atier this was carried out to investigate in the molar ratio $\left.11=8.0(1]=\mathrm{Fc}^{3+} / \mathrm{Sr}^{2+}\right)$.

In order to calculate the activation energy of the lerritization reaction, DTA scans of the coprecipitated powder were taken at various heating rates, namely, 2,5,10 and 20 ${ }^{\circ} \mathrm{C} / \mathrm{min}$. As the heating rate was increased, the cxothermic peak appeared on the high temperature side. Fig.3 shows the plot of the logarithm of the heating rate against the inverse of the phase temperature. The activation encrgy was calculated by the culuation of $\log _{u} 11=-E / 4.57 \times 1 / T_{11}+$ constant|[6] where $E$ is the activation energy, $h$ is the heating rate and $T_{m}$ is the pak lemperature. From the slope of the straightine, the activation energy was calculated to be $182.0 \mathrm{~kJ} / \mathrm{mol}(43.5 \mathrm{kcal} / \mathrm{mol})$. This value is nearly the same one calculated by Kulkari[7].

Fig. 4 shows the effect of subsequent heat treatment on magnetic properties of $\mathrm{Sr}$ $M$ ferrite fine particles coprecipitated at $n=8.0$. The values of $\sigma_{\mathrm{S}}$ increase with the increase of heat temperature 800 to $950^{\circ} \mathrm{C}$, and then do not change up to $1100^{\circ} \mathrm{C}$. The value of $\mathrm{H}_{c .}$ tend to increase with heat temperature, and have the maximum values at tcmperalure of $900^{\circ} \mathrm{C}$, and then decrease up to $1100^{\circ} \mathrm{C}$. The best magnetic properties is obtained by heal treatment at $900^{\circ} \mathrm{C}$, and $\sigma_{\mathrm{S}}=87.0 \times 10^{-6} \mathrm{~Wb} \cdot \mathrm{m} / \mathrm{kg}$ and $\mathrm{H}_{\mathrm{cl}}=501.3$ $\mathrm{kA}(6.3 \mathrm{kOe})$. In Stoner-Wohllarth model for the randomly oriented powders[8], $\mathrm{H}_{\mathrm{c}}$ is given by $H_{c J}=0.48\left(2 \mathrm{~K} / J_{\mathrm{s}}-J_{S} / \mu_{0}\right)$. This value of $H_{s J}$ was achieved $94 \%$ of the theoretical value, and $\sigma_{S}$ is $94 \%$ of single crystal value[9]. And the result of SEM observation ol Sr-M territe line particles alter heat treatment, these particles size was found to be about $0.2 \mu \mathrm{m}$ in the sample heated for $2 \mathrm{hs}$ al $900^{\circ} \mathrm{C}$.

Tabel 1 shows the preparation conditions and magnetic properties of $\mathrm{Sr}$ and $\mathrm{Ba}$ system ferrite fine particles in this cxperiment. As secn in this table, Sr-M lerrite Fine particles prepared by coprecipitation with $n=8.0$ and subsequent heat treatment have high saturation magnetization and coercivity .

Table 1 Preparation condition and magnetic properties of $\mathrm{Sr}$ and Ba ferrite fine particles.

\begin{tabular}{|c|c|c|c|c|c|c|c|c|}
\hline & \multirow{2}{*}{$\pi$} & \multirow{2}{*}{$\mathrm{pH}$} & \multicolumn{2}{|c|}{ Heat treatment } & \multirow{2}{*}{$\begin{array}{c}\sigma_{s} \\
(\times 10 \cdot \mathrm{Wb} \cdot \mathrm{m} / \mathrm{kg})\end{array}$} & \multirow{2}{*}{$\begin{array}{c}\mathrm{H}_{\mathrm{As}} \\
(\mathrm{KA} / \mathrm{m})\end{array}$} & \multirow{2}{*}{$\begin{array}{c}H_{\text {Lim }} \\
(\mathrm{KA} / \mathrm{m})\end{array}$} & \multirow{2}{*}{$\begin{array}{r}T_{\mathrm{c}} \\
\left({ }^{\circ} \mathrm{C}\right) \\
\end{array}$} \\
\hline & & & (C) & (h) & & & & \\
\hline \multirow[t]{2}{*}{$\begin{array}{l}\text { Sr-M } \\
\text { Ferrite }\end{array}$} & $8.0^{11}$ & 13.0 & 900 & 2 & $\begin{array}{c}87.0 \\
\text { (69.2 emu/g) }\end{array}$ & $\begin{array}{c}501.3 \\
(6.3 \mathrm{kOe})\end{array}$ & $\begin{array}{c}945.4 \\
(11.9 \text { KOe })\end{array}$ & $463 \pm 1$ \\
\hline & $10.5^{2}$ & 13.0 & 1000 & 2 & $\begin{array}{c}90.5 \\
\text { (72.0 emu/g) }\end{array}$ & $\begin{array}{c}350.1 \\
(4.4 \mathrm{kOe})\end{array}$ & $\left\{\begin{array}{c}915.1 \\
(17.5 \mathrm{kOe})\end{array}\right.$ & $463 \pm 1$ \\
\hline $\begin{array}{l}\text { 8a-M } \\
\text { Ferrite }\end{array}$ & 10.5 & 13.0 & 925 & 2 & $\begin{array}{c}86.0 \\
(68.4 \mathrm{emu} / \mathrm{g})\end{array}$ & $\begin{array}{c}408.2 \\
\text { (5.1 kOe) }\end{array}$ & $\begin{array}{l}791.0 \\
\text { (9.4 kOe) }\end{array}$ & 456 \\
\hline \multicolumn{9}{|c|}{$\begin{array}{l}\text { Sample preparation method after coprecipitation } \\
\text { Sr-M : 1) Boiling-Washing-Filtration-Drying-Heat treatment }(n=8.0) \\
\text { 2) Boiling-Filtration-Drying-Heat treatment }(n=10.5)\end{array}$} \\
\hline \multicolumn{9}{|c|}{ Ba-M : 3) Boiling-Washing-Filtration-Drying-Heat treatment } \\
\hline
\end{tabular}

\section{References}

[1]H.B.Beer and G.V.Planer : Br.Commum.Electron.,5(1958)939.

[2]C.D.Mec and J.C.Jeschke: J.Appl.Phys.,3 4(1963)1271.

[3]K.Haneda,C.Miyakawa and H.Kojima : J.Am.Ceram.Soc.,5 7(1974)354.

[4]W.Roos: J.Am.Ceram.Soc.,6 3(1980)601.

[5]C.Miyakwa, K.Haneda and K.Goto : IEEE Trans.Magn.,MA G23(1987)3134.

[6]S.Kulakrni,J Shrotri, C.E.Deshpande and S.K.Date : J.Mater.Sci.,2 4(1989)3739.

[7]S.D.Kulkarni,C.E.Deshpande,J.J.Shrotri;V.G.Gunjikar and S.K.Date :

Thermochin Acta,.153 (1989)47.

[8]E.C.Stoner and E.P.Wahlfarth: Phil.Trans.Roy.Soc.,A $240(1948) 599$.

[9]B.T.Shirk and W.R.Buessm : J.Appl.Phys.,4 0(1969)1294.

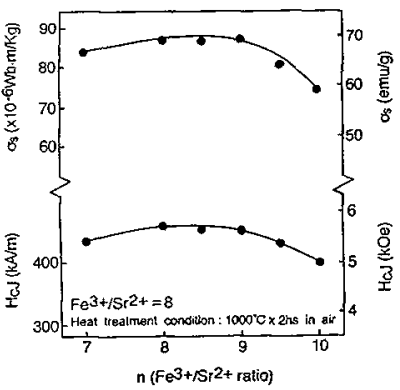

Fig.l Effect of $\mathrm{Fe}^{3+} / \mathrm{Sr}^{2+}$ ratio on magnetic propertics of $\mathrm{St}$ ferrite fine particles.

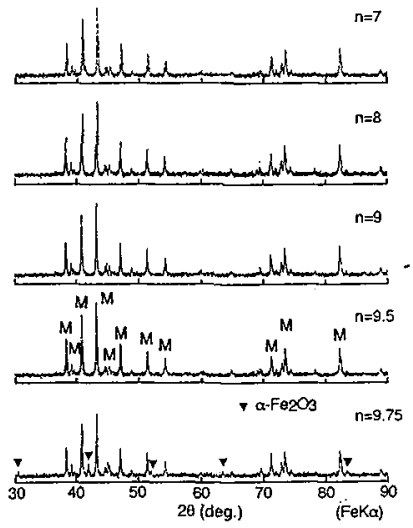

Fig.2 X-ray diffraction patterns of $\mathrm{Sr}$ lerrite fine particles.

Heating condition: $1000 \times 2$ hs in air.

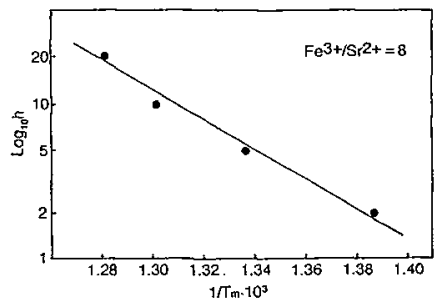

Fig.3 Plot of $\log _{1} d^{13}$ versus $1 / \mathrm{T}_{\mathrm{m}}$.

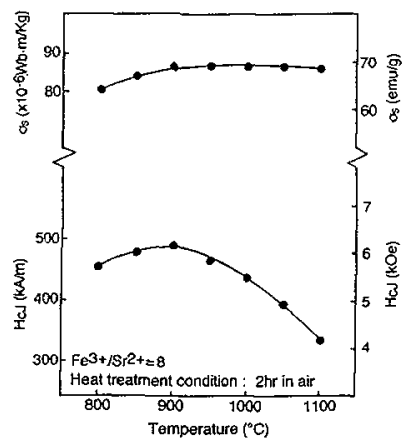

Fig. 4 Effect of heat-treatment on magnetic properties of Sr ferrite fine particles. 